\title{
Igreja-Comunhão: "uma multidão de fiéis" Eclesiologia de Teresa de Lisieux, uma releitura à luz do Concílio Vaticano II
}

\author{
Orientadora: Ana Maria de Azeredo Lopes Tepedino \\ Doutorando: Marcos Antonio de Araujo \\ Área de Concentração: Teologia Sistemático-Pastoral \\ Linha de Pesquisa: Religião e Modernidade
}

A tese quer demonstrar os fundamentos teológicos que determinam a Eclesiologia de Comunhão para a Unidade, partindo dos Escritos de Teresa de Lisieux, especialmente em seu Livro História de uma Alma, e na Teologia de Johann-Adam Möhler sobre a Unidade na Igreja. Faremos uma releitura da Eclesiologia de Comunhão do Concílio Vaticano II. Iremos explorar alguns aspectos como o "Centralismo do Amor" vivido e experimentado por uma multidão de pequenas almas que formam a Igreja, apresentado por Teresa de Lisieux, e, o argumento sobre a "Unidade na Igreja" na perspectiva de Comunhão de Johann-Adam Möhler, conforme sua concreta experiência. Trataremos de apresentar esta Unidade Eclesial a partir da noção de Multidão de Fiéis presente no Livro dos Atos dos Apóstolos: "A multidão dos que haviam crido era um só coração e uma só alma" (At 4, 32). Possuindo uma configuração eclesial que envolve a todos em vista da universalidade da salvação e das multiformes frentes de serviços e ministérios, retomaremos a noção de Igreja como Corpo de Cristo apresentada pela Teologia Patrística e Magistério da Igreja, e, também presente na Doutrina do Concilio Vaticano II, em consonância com a noção de Povo de Deus. A diversidade de membros desse Corpo, por sua interligação e abrangência, deve ser estendida para toda a humanidade, porém, agora, como Multidão de Fiéis. A Unidade na Igreja tornou-se, nos tempos atuais, um dos aspectos mais significativos para a Teologia, precisamente em razão do caráter da universalidade da salvação e da expressividade relacional entre as pessoas no mundo todo, por isso, a necessidade de uma fundamentação Teológica na perspectiva da Unidade Religiosa e do Diálogo diante de múltiplas iniciativas.

Palavras-chave: Igreja, comunhão, Teologia. 